\title{
13
}

\section{BELGIUM IN THE UN SECURITY COUNCIL}

\section{Still an active player?}

\author{
Michel Liégeois and Murat Caliskan
}

\subsection{Introduction}

Before the Second World War, most of the "small states"1 in Europe-including Belgium - pursued a hiding strategy. They preferred staying neutral to stay out of trouble in the hostile international environment, which was largely in line with the realist mindset. Once the two world wars proved that this strategy did not work out, the small states turned to the binding strategy, which aims to prevent conflict by supporting international rules and multilateral institutions that limit the action space of the great powers (Steinmetz \& Wivel, 2010). The binding strategy was boosted by the international context that, after the Second World War, has increasingly given small states the option to expand their influence over the great powers mainly through international organizations (Thorhallsson, 2019). International norms, rules and institutions have played a greater role in determining a state's behavior.

In many regards, Belgium has been a prominent example of a small state that has employed a binding strategy. It was not only a founding member of most of the basic international organizations such as the United Nations, the EU and NATO but it has also been a staunch supporter of multilateralism. As the Ministry of Foreign Affairs stated, multilateralism is in the DNA of Belgian foreign policy (Belgian Ministry of Foreign Affairs, 2020a). The fact that Belgium hosts both the NATO headquarters and the main bodies of the EU can be considered the symbol of the importance it has placed on international organizations.

Although other European small states have adopted a similar binding approach, Belgian policy, particularly in the United Nations Security Council (UNSC), distinguishes itself from other states of similar size. In 2018, Belgium was elected as a nonpermanent member (NPM) to the UNSC for the sixth time in its history, 
which makes it one of the most elected states in the world. Furthermore, it has been frequently praised for its active policy instead of being a niche player in the Council (Drieskens \& Wouters, 2009; Liégeois, 1993, 2009; Zeebroek, 2009). Indeed, despite the protracted regional dispute inside the country and its negative impact on the political life, Belgium appears to have consistently carried out an active policy in the UNSC, which merits further research. Focusing on the last two terms, this chapter aims to examine the performance of Belgium in the Security Council and explore whether Belgium maintains its active policy in its latest term (2019-20) as well. While it builds on various sources, it is supported by interviews with eight diplomats (four Belgian diplomats and four foreign diplomats) who experienced the Belgian presence in the Council. This chapter opens with a short description of being an elected member in the Security Council. In the following section, five features of successful small states are applied to the Belgian case to examine its performance of the last two terms. In conclusion, a short assessment of Belgium, as well as what makes Belgium different from other states, is discussed.

\subsection{Being an elected member in the UN Security Council}

The UN Security Council is a "world's cockpit where the decisions are binding upon all member states and are extremely important for those countries in crisis" (Simoens, 2019, A seat in the cockpit). This means that being in the Council gives an NPM a voice in the international system. However, for an NPM, it is like entering a theatrical stage as an actor in which both the script and its choreography have already been outlined by others (Wouters et al., 2009). There is an indisputable dominance of permanent members (PM) because, on top of the veto power, they also benefit from an institutional memory that has been accumulated throughout decades of practical experience. Such comprehensive knowledge allows PMs to enjoy a clear advantage over elected members, particularly in long-lasting diplomatic processes. In this respect, the real power of PMs not only stems from preventing things from being said but also from the power over what is going to be said (Xavier do Monte, 2016). As Johan Verbeke-Belgian permanent representative to the United Nations between 2004 and 2008-noted, "it is the PMs who will decide about your fate in the Security Council, and make or break your reputation" (Verbeke, 2018).

Yet, despite this dominance, there is still a leeway for NPMs to exercise influence in the UNSC. First, the veto is only a negative power; it does not help the PMs in any way when they want the UNSC to adopt a resolution. They need the votes of at least four elected members as nine affirmative votes are required for any resolution to be passed. One should remember that it was the lack of these necessary nine votes rather than the threat of French veto that prevented the draft US-UK resolution from being endorsed in the lead-up to the Iraq War (Conley Tyler \& Pahlow, 2014). Second, as the variety and volume of the Council's tasks 
have widened since the end of the Cold War, the opportunities and tools that elected numbers can use also have increased. Third, small- and middle-sized countries have some advantages over PMs resulting from their smallness. For instance, they are free from hegemonic baggage and therefore less limited in their actions. In some cases, a proposal by an NPM has a greater chance of being considered as it allows to avoid biased reaction that would have been triggered by a PM. Additionally, small size usually means a much easier process of internal consultation, thus much greater flexibility (Liégeois, 2009).

The history of the Security Council confirms that small states can deliver a successful performance in the Council when they have certain characteristics. For instance, Melissa Conley Tyler and Eleanor Pahlow (2014) identified five key factors based on the case studies of New Zealand (1993-94) and Mexico (2009-10) memberships. They found that "active participation", "coalition building", "strong leadership skills", "confidence-building" and "engagement of organizations with real interests" are important factors that determine the ability of elected members to be influential in the UNSC. Andrea Ó Súilleabháin (2014) found seven good practices of effective small states in a report written for the International Peace Institute (IPI). His findings that are based on the interviews and roundtables with 54 small-state UN missions can be paraphrased as the following: "coalition building", "prioritization", "diplomatic skills and highquality personnel" and "innovative and creative leadership". Baldur Thorhallsson (2012) suggests that the qualitative variables such as "diplomatic skills", "knowledge and initiatives", "image or reputation", "strong leadership", "excellent coalition-building skills" and "an ability to prioritize heavy workloads" are important factors to explain their accomplishments within the UNSC. Based on these case studies and wider literature (see also Langmore \& Farrall, 2016; Langmore \& Thakur, 2016; Liégeois, 2009; Schrijver \& Blokker, 2020; Verbeke, 2018), we have identified five key factors that explain the success of an NPM, "a commitment to the active participation", "positive image", "competence", "coalition-building skills" and "a balanced idealistic pragmatic approach". In the following sections, these five characteristics are applied to Belgium in order to evaluate its performance during its last two terms.

Nonetheless, as all interviewees noted, the successful performance of an elected member, especially of a small power, does not necessarily translate to a substantial impact on the overall policy of the UNSC. One can find numerous cases where elected members cannot make any meaningful contribution to the resolution of regional crises, as it occurred in the cases of Syria, Ukraine or Libya. For instance, it would not be reasonable to expect Belgium to initiate a fundamental solution to the Syrian crisis, given that the PMs also have a stake in these crises. However, it can be considered a successful bid of Belgium-as a penholder of humanitarian issues in Syria - when it paved the way for a Security Council Resolution on humanitarian border crossings despite the clear opposition of Russia and China. That is why this chapter has evaluated Belgium based on the premise that an elected member has inherently limited ability to influence the overall policy of the Security Council. 


\subsection{Belgium as an elected member of the UN Security Council}

\subsubsection{Active participation}

First and foremost, the government of an NPM has to have an ambition and the political will to play an active role in the Council. The meticulous preparation of the Ministry of Foreign Affairs, the special sessions of the Parliament and the strong support of the high-level leadership signal the ambition that Belgium has for the membership (Liégeois, 2009). In both mandates, the visits of highlevel leaders, namely the Belgian King, Prime Minister and Minister of Foreign Affairs to the Council and their active participation in the debates, demonstrate the political will for active participation. Another sign of Belgian determination for being inside the Council is the fact that immediately after the completion of its last two mandates, Belgium announced its candidacy for the next mandate. For instance, just one month after 2019-20 term ended, Sophie Wilmès, Minister of Foreign Affairs, announced Belgian candidacy for the term 2037-38 (Wilmès, 2021). Furthermore, a closer look at its performance in the Council reveals that Belgium uses every tool that is important for an NPM, such as the chairmanship of subcommittees, the penholder role, the informal meetings and the presidency, as discussed in the following paragraphs.

The chairmanship of a subsidiary body is an important instrument for an NPM as it allows to increase its visibility and make progress in the existing practices of the United Nations. This, of course, requires considerable effort as the efficiency of subsidiary bodies mainly relies on the input of the chairs. Belgium has always been ambitious in terms of engaging in the work of subsidiary bodies. In its previous term (2007-08), it chaired three sanctions committees, Al Qaeda/Taliban, Ivory Coast and Iran. It also presided over one Informal Working Group on International Tribunals. Its commitment and qualitative work, particularly in the chairmanship of the very technical Al Qaida/Taliban Sanctions Committee as well as the Informal Working Group on International Tribunals, made Belgium a respected member of the UNSC (Vandervelden, 2009). During the last term, Belgium assumed the chairmanship of the Somalia Sanctions Committee and the Children and Armed Conflict Working Group (CACWG). It also served as a facilitator for the issue of Iran's nuclear program implementation. The significant progress achieved in each subsidiary body indicates its active participation. For instance, as the chair of CACWG, Belgium managed to have a record number of 13 conclusions adopted on specific geographical issues, including Myanmar, Yemen and Syria, out of 14 files in total. No NPM in the Council has ever achieved as many conclusions as Belgium in the course of its mandate (Interview with a Belgian diplomat, January 05, 2021).

Another instrument that can be utilized by an NPM is the penholder system. The penholder role refers to a member of the Council that leads the negotiations and drafts the text of an outcome, whether it is a resolution or a presidential statement. It goes beyond "drafting" a text, which has been a regular practice 
since the inception of the Council. "The penholder takes the initiative on all Council activities concerning that situation, such as holding emergency meetings, organizing open debates, and leading visiting missions" (Security Council Report, 2018, p. 2). Furthermore, in contrast with the chairmanships of the subsidiary bodies, the penholder system has been the domain of the PMs, particularly the P3 (United States, United Kingdom and France). In theory, "any member of the Security Council may be a penholder" (Security Council Report, 2020 a, para. 2); however, in practice, few elected members can assume this role. It usually requires an NPM to take initiative in order to grab a penholder role (Security Council Report, 2018). As a diplomat of an NPM stated, "an elected member needs to fight and convince other members of the fact that it is capable for this role" (Interview with a Foreign Diplomat3, February 03, 2021). Figure 13.1 demonstrates the number of penholder roles that is carried out by each NPM in 2020 (Security Council Report, 2020a). Acting as a penholder on three topics can be regarded as a sign of Belgian active participation in the Council.

Informal meetings are also important tools for NPMs to influence the work of the UNSC. These meetings are usually held when there is no Council agreement for a formal meeting. In some cases, they may become an opportunity for NPMs to advance their own policies as they usually serve as a preparation for further debates in the Council. The most notable forms of informal meetings are "informal interactive dialogues" and "Arria-Formula Meetings". While both forms are informal with no official records and outcomes, informal interactive meetings host high-level participants of non-Council members, whereas Arria-Formula Meetings are more flexible meetings convened to hear

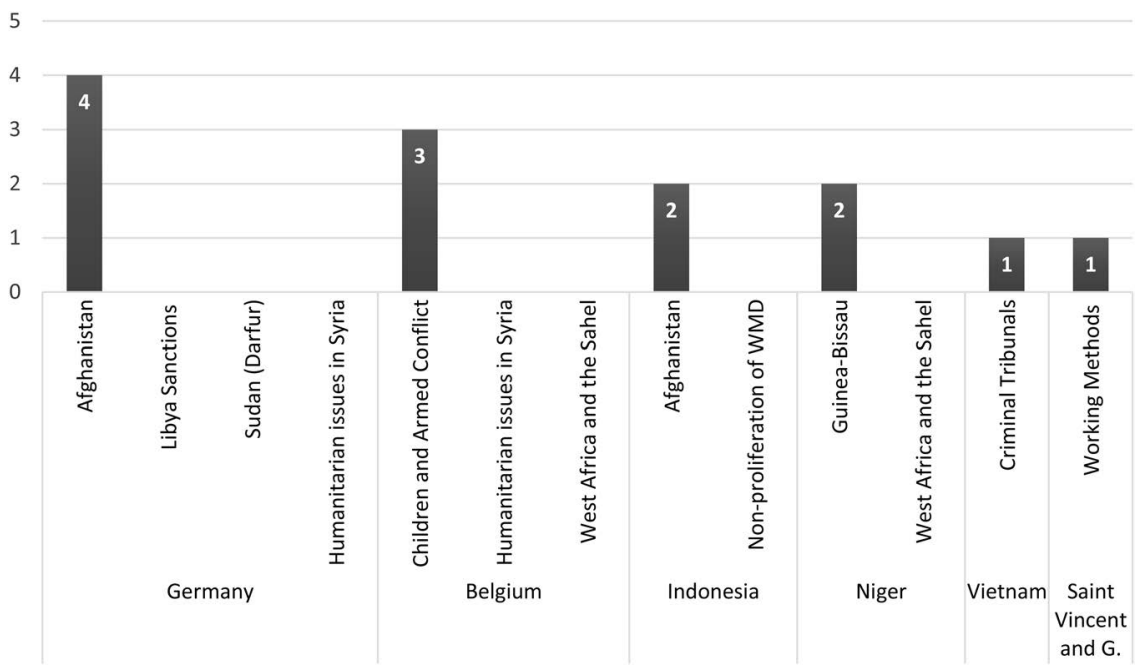

FIGURE 13.1 The number of penholder tasks of NPMs (2020) 


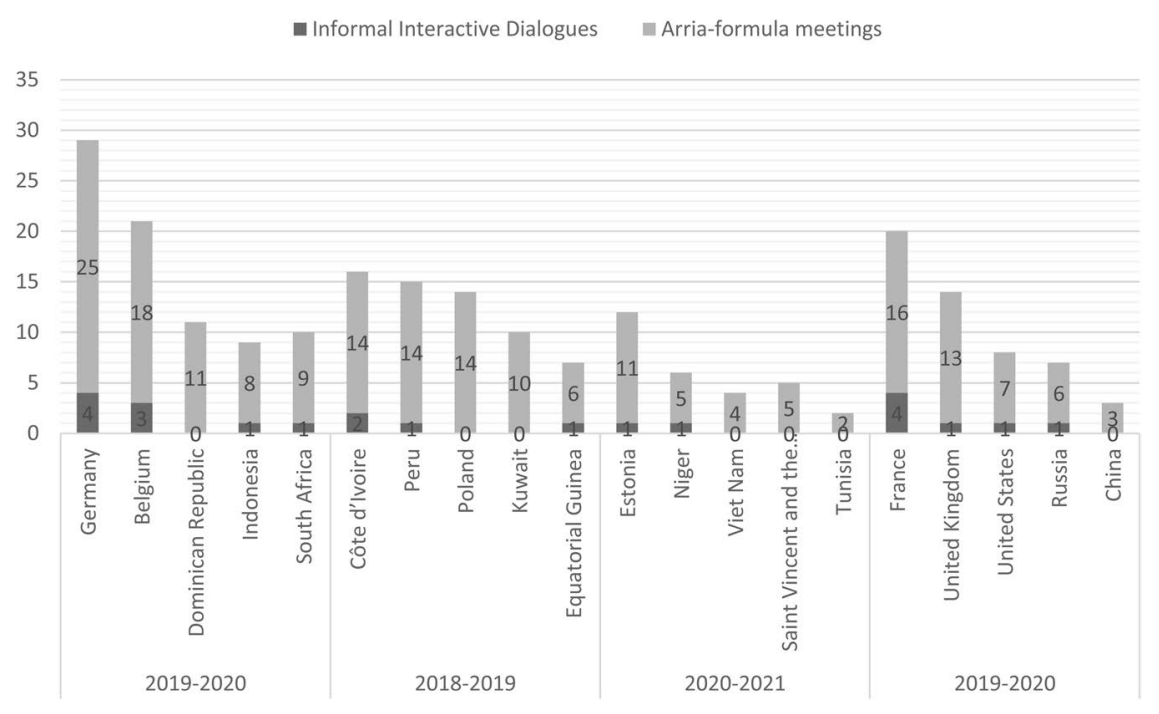

FIGURE 13.2 The number of informal meetings initiated by Council members

the views of experts and organizations (Daws \& Sievers, 2020; Security Council Report, 2020b). These meetings usually reflect a member state's endeavor in order to take initiative or contribute to the United Nations' work. Therefore, the number of informal meetings initiated by an NPM can be regarded as an aspect of its active performance. As seen in Figure 13.2, Belgium is the NPM that has requested the greatest number of informal meetings after Germany, which can be seen as another aspect of Belgian active policy. ${ }^{2}$

The most notable opportunity for the elected members is the presidency. According to a foreign diplomat, "elected members pay a lot of attention to the presidency. It can be considered as a measure of success for the elected members" (Interview, February 1, 2021). Indeed, an NPM can use the presidency to shape the program of the month and present a theme that is not formally on the agenda. Belgium has been good at using its presidency effectively in terms of putting its own stamp on proceedings. As described by a foreign diplomat, "everyone accepted that Belgian presidency was very well-planned and organized. If you compare it to the other months, they had a lot of external briefers. All their key topics, including children and armed conflict, are reflected very well during their presidency" (Interview, February 01, 2021).

This can also be recognized by the new themes that Belgium has brought into the attention of the Council during its presidencies. For instance, in its previous term, in June 2007, Belgium introduced a debate for the first time in the Council on the delicate topic, "the role of natural resources in conflict areas", which led to a consensus and the adoption of a presidential statement (Wouters, Demeyere, et al., 2009). In its second presidency, in August 2008, Belgium organized a thematic debate on the "UNSC's working methods", which 
had not been debated since 1994 in the Council (Grauls \& Verbeke, 2009). In its current term, in February 2020, Belgium introduced another important theme that has not been discussed in the Security Council. It convened an open debate on "Transitional justice in conflict and post-conflict situations" as one of the signature events of its presidency, which eventually received a major support from the members of the Council (Security Council Report, 2020c). This can be seen as a success in terms of setting the Council's agenda, given the difficulty of introducing thematic debates in the UNSC, where the day-to-day business usually focuses on geographic areas of work. This review shows that Belgium strives to use every instrument possible to actively participate and influence the Council.

\subsubsection{Positive image}

A positive image is also an important source for success and one of the key factors that enables an NPM to play a meaningful role in the Council. Belgium has been generally known as a "reliable" and "predictable" country as confirmed by all interviewees talked in this study, if not a "bridge builder" as claimed by Ministry of Affairs (Belgian Ministry of Foreign Affairs, 2020a). Being aware of its own image, Belgium chose an official slogan-“Fostering Consensus. Acting for Peace"-during the last election campaign (Belgian Ministry of Foreign Affairs, 2016). The high rate of vote obtained in the elections shows not only the success of this strategy but also the international community's trust in Belgium. A foreign diplomat who was in the Council during 2018-19 also confirms Belgian role as a bridge builder:

There are few countries that have this image. But I can confirm that a common perception in the Council is that Belgium is a bridge-builder. It was not only good in its relations with NPMs, but it was also instrumental in Middle East issues. It was also very successful to articulate our position to Europeans. Belgium achieved a tremendous job in Syrian humanitarian issues due to its good relations with other countries. They had ability to reach out every actor around the globe, not necessarily to the EU, sometimes they reach out even to Latin America.

(Interview, October 28, 2020)

Having no particular stance on sensitive issues, lack of vested interests in most of the current international conflicts, its role as an honest broker and the very smallness of Belgium contribute to this positive image (Liégeois, 2009). Yet, the positive image and credibility cannot be gained in one day. It is the result of years of endeavor and the investment in the United Nations' work. As one senior Belgian diplomat stated, "Belgium is a congenital multilateralist", which supports the interest of the international community and the rule of law since the 
foundation of the United Nations. This plays an important role for having a good standing in the United Nations (Interview, February 06, 2021).

\subsubsection{Competence}

The competence simply means having the required knowledge and diplomatic skills. Belgium traditionally has knowledge and expertise in Central Africa, particularly in the Democratic Republic of the Congo (DRC), that is acknowledged by the international community (Grauls \& Verbeke, 2009). It is regularly consulted on DRC by the PM even at times when it is not a member of the UNSC (Zeebroek, 2009). However, in addition to its vast knowledge in DRC and Central Africa, Belgium's active involvement in the UNSC over the years appears to have brought expertise on multiple themes. For instance, Belgium acted as the chairman of the newly established Iran Sanctions Committee during its previous term, for which it was widely praised by other states (Sauer, 2009), while in the current term, it acts as a facilitator on the issue of the Iran nuclear program. As another example, Belgium has always paid particular attention to the independence and the efficient functioning of international tribunals. That is why "fighting against impunity" through International Criminal Court (ICC) was one of its priorities in the previous term (Grauls \& Verbeke, 2009). It now acts as a focal point for the ICC and continues to use its expertise on the same theme. Another theme that Belgium has gained expertise in is the "protection of civilians", especially women and children, in the conflicts. During the previous term, an active performance on the subject already allowed Belgium to distinguish itself; yet in the 2019-20 term, it assumed the chairmanship of Children and Armed Conflict Working Group.

Besides the expertise on thematic issues, it is essential to demonstrate diplomatic skills and capabilities to master ongoing themes in the Council's agenda. Previous terms confirmed that Belgium can feed its representative in the Council with information about the most recent developments (Grauls \& Verbeke, 2009) through a well-established diplomatic network that is spanning all five continents (Belgian Ministry of Foreign Affairs, 2020c). Furthermore, the high quality of Belgian diplomats is also an important factor that makes them competent enough to deliver a successful performance. According to a political coordinator of an NPM, Belgian diplomats are "exceptionally good". He describes his counterpart from Belgium as the following:

He was always ready to listen to you, he was very good at articulating delicate matters, he was always well-prepared, he knew everybody's position, he even knew what we voted before on the subject. It is not only limited to my area of responsibility, what I heard from my colleagues, all Belgium team was exceptional.

(Interview, October 28, 2020) 


\subsubsection{Coalition building}

Competency is not enough on its own to become influential in the Council. Since a degree of consensus is essential for the UNSC to function well, collaborations with both PMs and NPMs inside the Council, or with other groups outside the Council, are crucial to achieve the desired outcomes. Of course, this also requires enormous time and effort. Small states, with their limited resources, need to strike the right balance between conducting an efficient daily work and building coalitions for future outcomes.

In this regard, Belgium benefits from its long-standing partnerships. Brussels can lean on its close ties with Benelux countries to the degree that they have seconded diplomats in the Council (Belgian Ministry of Foreign Affairs, 2020b). Belgium is also a member of the EU and enjoys certain benefits of EU membership, especially in terms of access to inner circle information (Wouters et al., 2009). Yet, its endeavor for building coalitions is not limited to the inner circle of traditional partners. For instance, it is a member of an informal group of "LikeMinded States on Targeted Sanctions"3, which advocates fair and clear procedures for a more effective UN sanctions system, which is a theme that Belgium has always placed value on. Being part of such a group, which has consistently been active at the level of the Security Council, clearly provides leverage for the implementation of Belgian policies on sanctions.

Belgium has also been active in strengthening cooperation among the elected members. One notable example of this effort was the organization of a meeting of elected members (E-10) in Brussels, which was called "Brussels Dialogue", at the end of 2019 (Belgian Ministry of Foreign Affairs, 2019). It is difficult to measure the impact of such a meeting on the subsequent activities of the Council. However, as the Belgian permanent representative Pecsteen indicated, consensus among NPMs could lead to a resolution even on a delicate matter such as Syria. He further explained the role of cooperation with the following example: "A proposed resolution for a cease-fire around Idlib (Syria) was struck down by a nyet ('no' in Russian) from Russia and China. Nonetheless, as non-permanent members, we were able to exert a certain pressure on those two countries. No-one likes to feel isolated. Ultimately, we even had an effect on the ground: Syria announced a unilateral cease-fire" (Simoens, 2019, Right to veto).

\subsubsection{A balanced approach}

The UNSC certainly does not fully meet its primary responsibility that is to "maintain international peace and security", especially when the interests of PMs are at stake. However, the UNSC does matter on many occasions. As Wouters et al. (2009) noted, "aside from the symbolism inherent in having a UNSC decision on a particular matter, actions that range from mere recommendations up until the use of armed force have an impact on the ground". Thus, an 
NPM should consider the constraints and power struggles within the Council and strike a right balance between taking always the high moral ground and achieving some tangible outcomes that can make the difference for people in conflict-affected areas.

Belgium appears to have adopted an astute balance between an idealistic and a pragmatic approach during its terms in the Council. In the words of Grauls and Verbeke, former permanent representatives to the Security Council, Belgium has chosen a moderate rather than a staunch stance (Grauls \& Verbeke, 2009). One prominent example of Belgium's moderate stance is its approach toward the Security Council reform. It was one of the countries advocating a restriction in the range and the use of the veto power at the foundation of the United Nations (Loridan, 1946). Since then, it has traditionally supported a reform of the UNSC in terms of both its composition and working methods. However, knowing that a debate on UNSC reform implies investing one's political capital, it prefers an action in small steps and consultation with other members rather than one big reform package (Vandervelden, 2009). According to Ambassador Pecsteen, abolishing the veto power, for instance, is a too radical demand because "without the right to veto, some of the major powers might withdraw from the Security Council, but it's of the utmost importance that all the major powers do stay around the table". Instead, Belgium advocates a limited veto power that would be a more feasible approach (Simoens, 2019, Right to veto). In short, one can claim that Belgium adopts a balanced approach in the Council, which can be summarized as a "principled pragmatism" (Rodiles, 2013) or the "use of pragmatism to achieve ideals".

\subsection{Conclusion}

Belgium takes a particular role on the international stage. Even though it is generally considered a minor player, our analysis of the last two mandates in the UNSC reveals that Belgium has been using its terms-including its last term-to be influential in the Council, instead of being a niche player. Supported by its leadership, Brussels developed a clear policy of being active in the Security Council. An image of "reliable partner" that has been gained throughout the decades together with diplomatic and coalition-building skills has enabled Belgium to play a meaningful role inside the Council. On top of this, a pragmatic approach based on the sober assessment of its own position made Belgium influential, sometimes even disproportional to its size in power politics.

What is more, even though most small states pursue a similar binding strategy, Belgian policy in the UNSC distinguishes it from other states of similar size in several aspects. First of all, being active inside the Council appears to have become "a state policy" of Belgium rather than a particular government's policy. Starting from the first delegation of Belgium at San Francisco, which was headed by Mr. Paul-Henri Spaak, then Minister of Foreign Affairs, 
particular importance has been attached to the UN mission. At its foundation, supporting United Nations was regarded as a long-standing interest of Belgium due to the geographic, economic and political reasons (Loridan, 1946). Furthermore, the active participation of Mr. Spaak during the foundation of the United Nations made him the president of the first General Assembly (Loridan, 1946). This notion of being active in the United Nations in general and the Security Council in particular has not changed to date.

The consistency of Belgian active policy has been best tested during the world's longest governmental crisis, which coincided with the last two terms in the Council. In the aftermath of both 2007 and 2018 elections, Belgium found itself in a political crisis that mainly arises from the growing political gulf between two main regions (Chini, 2020). The political parties could not form a new government over six months following the elections. Despite a temporary government formed in March 2008, the crisis continued until the end of 2011 ("Le nouveau gouvernement belge", 2011). A similar government crisis in the same decade began at the end of 2018, which this time took more than 16 months for political parties to form a new government (Messoudi, 2020). In spite of these two political crises at home, Belgium succeeded in delivering an active performance in the Council, which confirms that active policy has become a Belgian state policy. This can be better understood when compared with other elected members, even with the ones praised for their successful membership in the Council such as Australia (2013-14), in which political parties support quite different views on the membership and a government change might cause serious impact on its policies in the Council (Langmore \& Farrall, 2016).

A reflection of having a constant policy of being active can also be seen in the number of mandates. Belgium has been quite ambitious to be inside the Security Council as many times as possible. Having completed its sixth mandate, Belgium is one of the most elected countries in the world, and arguably, it is the most elected small state. ${ }^{4}$ As a small power, it has thus accumulated the highest level of experience of diplomacy inside the UNSC (Liégeois, 2009). Another aspect that distinguishes Belgium from other states is the high number of votes it has received in the elections of the Security Council. Belgium won all elections in the first round and obtained 43 votes out of 51 in 1946, 52 votes out of 58 in 1954, 104 votes out of 113 in 1970, 142 votes out of 154 in 1990, 180 votes out of 189 in 2006 and 181 votes out of 193 in 2018 (Security Council Report, 2020d). This is a remarkable history of vote rate when compared with other most elected countries like Canada ${ }^{5}$ or the Netherlands, which could win some of their elections in the following rounds at a narrow margin. Although it was an unopposed candidate of its regional group in the last two terms, this consistent high rate of the vote obtained in the General Assembly can be regarded as a sign of the international community's trust in Belgium. 
All in all, given its performance in the last two mandates, it appears that Belgium maintains its ambition and active policy in the UNSC as part of its broader policy of multilateralism. The aforementioned elements tend to support the argument that alongside multilateralism, engaging in the Security Council has also become part of Belgian diplomatic DNA. However, one should note that it would be illusory to infer from the last two mandates that a lasting political crisis does not affect Belgian capacity to weigh on the international stage. What makes Belgium exceptional now is the paradox between the success in foreign policy and the fragility in domestic policy. However, this paradox also cast a shadow on the future of Belgium on the international stage in general and as part of the UNSC in particular.

\section{Notes}

1 There is not a common definition of "a small state" in the studies of international relations. Traditionally, smallness has been measured with quantitative factors such as the size of population, territory, economy or military. For the population size, which is the single most common feature, the threshold ranges from 1 million to 30 million, with the most common threshold at 10 million. However, smallness is contextual and may depend on where the state is located, how it is perceived by itself and other states and its relative power to other states. In this respect, while it is not easy to make an absolute categorization, Belgium can be considered a small state that partially shows middle power state characteristics. For the purpose of this chapter, it is classified as a small power.

2 The numbers for the previous five elected members belong to the same period of their own term. The numbers for the following five elected members, the period is only one year (2020). Source: "Annex 2018 Highlights of Security Council Practice", accessed December 21, 2020, https://unite.un.org/sites/unite.un.org/files/app-schighlights2018/doc/Highlights\%20Paper\%202018\%20Annex.pdf;"Annex2019Highlights ofSecurity CouncilPractice",accessedDecember21,2020,https://www.un.org/securitycouncil/ sites/www.un.org.securitycouncil/files/highlights_2019_annex.pdf\#page=3; “Arria-Formula Meetings",Security CouncilReportWebsite,accessedDecember 17,2020, https://www.securitycouncilreport.org/atf/cf/\%7B65BFCF9B-6D27-4E9C-8CD3CF6E4FF96FF9\%7D/working_methods_arria_formula_meetings.pdf; "Informal Interactive Dialogues", Security Council Report Website, accessed August 19, 2020, https:// www.securitycouncilreport.org/atf/cf/\%7B65BFCF9B-6D27-4E9C-8CD3-CF6E4F F96FF9\%7D/working_methods_informal_interactive_dialogue.pdf.

3 The group consists of Austria, Belgium, Costa Rica, Denmark, Finland, Germany, Liechtenstein, the Netherlands, Norway, Sweden and Switzerland. See for instance "the Statement delivered by Ambassador Olof Skoog of Sweden on behalf of the Group of Like-Minded States on Targeted Sanctions at the UN Security Council open debate on working methods of the Security Council", June 6, 2019, available at https://www. government.se/speeches/20192/06/statement-by-ambassador-olof-skoog-of-swedenon-behalf-of-the-group-of-likeminded-states-on-targeted-sanctions/.

4 Here are the most elected countries: Japan 11; Brazil 10; Argentina 9; Colombia, India, Pakistan and Italy 7; Belgium, Canada, Germany, the Netherlands and Poland 6 times. Among these countries, Belgium is the smallest country, both in terms of population and size. The Netherlands can be considered the next smallest country, which is frequently regarded as a middle power as well.

5 Canada even experienced the political humiliation of not being elected two times in a row (2010 and 2020) despite expensive campaigns and heavy political support. 


\section{References}

Belgian Ministry of Foreign Affairs. (2016). Belgium at the United Nations: A History of Fostering Consensus and Acting for Peace. Retrieved 20 August 2020, from https://diplomatie. belgium.be/en/documentation/ documentation_un

Belgian Ministry of Foreign Affairs. (2019). Belgium Assembles Elected Members of the UN Security Council in Brussels. Retrieved 22 August 2020, from https://diplomatie.belgiu m.be/en/newsroom/news/2019/belgium_assembles_elected_members_un_security_ council_brussels

Belgian Ministry of Foreign Affairs. (2020a). Belgian UN Policy. Retrieved 15January 2021, from https://diplomatie.belgium.be/en/policy/international_institutions/united_nations/ belgian_un_policy

Belgian Ministry of Foreign Affairs. (2020b). Belgium in the UN Security Council. Retrieved 22 June 2020, from https://diplomatie.belgium.be/en/policy/policy_areas/peace_and_ security/in_international_organisations/united_nations/belgium_un_security_council

Belgian Ministry of Foreign Affairs. (2020c). Crisis Communication Belgian Foreign Affairs Internationally Recognised. Retrieved 21 August 2020, from https://diplomatie.belgium.be/en/newsroom/news/2020/crisis_communication_belgian_foreign_ affairs_internationally_recognised

Chini, M. (2020). The Basics of Belgium's Government Formation. The Brussels Times, 25 September 2020.

Conley Tyler, M., \& Pahlow, E. (2014). Australia on the UN Security Council 2013-14: A Voice for Small and Medium Countries? The Round Table 103(1): 95-108.

Daws,S.,\&Sievers,L.(2020).Arria-Formula Meetings.Retrieved17December2020, from https:// www.securitycouncilreport.org/atf/cf/\%7B65BFCF9B-6D27-4E9C-8CD3-CF6E4 FF96FF9\%7D/working_methods_arria_formula_meetings.pdf

Drieskens, E., \& Wouters, J. (2009). Introduction: The 2007-2008 Belgian Membership of the UN Security Council in Perspective. In J. Wouters, E. Drieskens, \& S. Biscop (Eds.), Belgium in the UN Security Council: Reflections on the 2007-2008 Membership. Antwerp, Oxford, Portland: Intersentia, pp. 1-196.

Grauls, J., \& Verbeke, J. (2009). Serving at the UN Security Council: An Insider's View. In J. Wouters, E. Drieskens, \& S. Biscop (Eds.), Belgium in the UN Security Council: Reflections on the 2007-2008 Membership. Antwerp, Oxford, Portland: Intersentia, pp. 1-196.

Langmore, J., \& Farrall, J. (2016). Can Elected Members Make a Difference in the UN Security Council? Australia's Experience in 2013-2014. Global Governance 22(1): 59-77.

Langmore, J., \& Thakur, R. (2016). The Elected but Neglected Security Council Members. Washington Quarterly 39(2): 99-114.

Le Monde. (2011). Le nouveau gouvernement belge prête serment après une crise record, 6 December.

Liégeois, M. (1993). La Belgique au Conseil de sécurité de l'Organisation des Nations Unies. Courrier Hebdomadaire Du CRISP 1401-1402(16): 1-56.

Liégeois, M. (2009). The Role of Small Powers in the UN Security Council: The Case of Belgium. In J. Wouters, E. Drieskens, \& S. Biscop (Eds.), Belgium in the UN Security Council: Reflections on the 2007-2008 Membership. Antwerp, Oxford, Portland: Intersentia, pp. 1-196.

Loridan, W. (1946). Belgium and the United Nations. The Annals of the American Academy of Political and Social Science 247(3): 165-170.

Messoudi, H. (2020). Gouvernement Vivaldi: découvrez le contenu de l'accord du nouveau gouvernement belge, RTBF, 30 September.

Rodiles, A. (2013). Non-Permanent Members of the United Nations Security Council and the Promotion of the International Rule of Law. Goettingen Journal of International Law 5(2): 333-373. 
Sauer, T. (2009). The Unbearable Lightness of UN Security Council Resolutions: The Case of Iran. In J.Wouters, E. Drieskens, \& S. Biscop (Eds.), Belgium in the UN Security Council: Reflections on the 2007-2008 Membership. Antwerp, Oxford, Portland: Intersentia.

Schrijver, N. J., \& Blokker, N. M. (Eds.) (2020). Elected Members of the Security Council: Lame Ducks or Key Players? Leiden: Nijhoff Law Specials.

Security Council Report. (2018). The Penholder System. Retrieved 17 August 2020, from https://www.securitycouncilreport.org/research-reports/the-penholder-system.php

Security Council Report. (2020a). Lead Roles within the Council in 2020: Penholders and Chairs of Subsidiary Bodies. Retrieved 16 August 2020, from https://www.securitycouncilreport. org/monthly-forecast/2020-02/lead-roles-within-the-council-in-2020-penholdersand-chairs-of-subsidiary-bodies.php

Security Council Report. (2020b) Informal Interactive Dialogue. Retrieved 17 August 2020, from https://www.securitycouncilreport.org/atf/cf/\%7B65BFCF9B-6D27-4E9C8CD3-CF6E4FF96FF9\%7D/working_methods_informal_interactive_dialogue.pdf

Security Council Report. (2020c). Transitional Justice Open Debate. Retrieved 19 August 2020, from https://www.securitycouncilreport.org/whatsinblue/2020/02/transitional-justice-open-debate.php

Security Council Report. (2020d) Elections for Non-Permanent Members of the Security Council: A Comprehensive Review 1946-2019. Retrieved 17 July 2020, from https://www. securitycouncilreport.org/atf/cf/\%7B65BFCF9B-6D27-4E9C-8CD3-CF6E4F F96FF9\%7D/elections_table_2020.pdf

Simoens, C. (2019, December 17). Behind the Scenes at the Security Council. Retrieved 17 July 2020, from https://www.glo-be.be/en/articles/behind-scenes-security-council

Steinmetz, R., \& Wivel, A. (2010). Introduction. In R. Steinmetz \& A. Wivel (Eds.), Small States in Europe: Challenges and Opportunities. Farnham: Ashgate, pp. 3-14.

Súilleabháin, A. Ó. (2014). Small States at the United Nations: Diverse Perspectives, Shared Opportunities. New York, NY: International Peace Institute.

Thorhallsson, B. (2012). Small States in the UN Security Council: Means of Influence? The Hague Journal of Diplomacy 7(2): 135-160.

Thorhallsson, B. (2019). Small States and the Changing Global Order: What Small State Theory Can Offer New Zealand Foreign Policymaking. In A.-M. Brady (Ed.), Small States and the Changing Global Order. New Zealand Faces the Future. Cham: Springer.

Vandervelden, T. (2009). Reforming the UN Security Council: Searching for an End to a Never-Ending Story. In J. Wouters, E. Drieskens, \& S. Biscop (Eds.), Belgium in the UN Security Council: Reflections on the 2007-2008 Membership. Antwerp, Oxford, Portland: Intersentia.

Verbeke, J. (2018). What Is It Like To Be a Non-Permanent Member of The UN Security Council? Brussels: EGMONT Royal Institute for International Relations.

Wilmès, S. (2021). Intervention sur le bilan du mandat de la Belgique au Conseil de sécurité des Nations Unies. Retrieved 15 March 2021, from https://wilmes.belgium.be/fr/ intervention-sur-le-bilan-du-mandat-de-la-belgique-au-conseil-de-securite-desnations-unies

Wouters, J., Demeyere, B., \& Hachez, N. (2009). The 2007-2008 Membership of the UN Security Council: Maximising Opportunities and Minimising Constraints? In J.Wouters, E. Drieskens, \& S. Biscop (Eds.), Belgium in the UN Security Council: Reflections on the 2007-2008 Membership. Antwerp, Oxford, Portland: Intersentia, pp. 1-196.

Wouters, J., Drieskens, E., \& Biscop, S. (Eds.). (2009). Walking on Eggshells: Non-Permanent Members Searching for an EU Perspective at the UN Security Council. In J. Wouters, E. Drieskens, \& S. Biscop (Eds.), Belgium in the UN Security Council: Reflections on the 20072008 Membership. Antwerp, Oxford, Portland: Intersentia, pp. 1-196. 


\section{Michel Liégeois and Murat Caliskan}

Xavier do Monte, I. (2016). The Pen is Mightier than the H-Bomb: Language and Power in the United Nations Security Council. Interventions 18(5): 669-686.

Zeebroek, X. (2009). Belgian Expertise in 'The Congo': A Paradox. In J. Wouters, E. Drieskens, \& S. Biscop (Eds.), Belgium in the UN Security Council: Reflections on the 20072008 Membership. Antwerp, Oxford, Portland: Intersentia, pp. 1-196. 